\title{
The Democratic Deficit and Federalism in Nepal: Is it a Cure or Part of the Problem?
}

\author{
GANGA BAHADUR THAPA \& JAN SHARMA
}

\begin{abstract}
Since the second democratic opening in 1990, Nepal has suffered from a democratic deficit due to the new leaders' failure to institutionalise democracy by promoting inclusion, representation, and responsiveness. The concept of federalism, as argued in Nepal today, reflects the failure of the past and the determination to give local governance the real political and economic power. The fringe leftist and rightist parties oppose federalism, arguing that it will create deep divisions. Some of them even assume that the country may ultimately disappear altogether. In view of the widespread popular support, the challenge is to use federalism as an opportunity for prudently promoting inclusive, participatory, and responsive governance in the interest of economic prosperity and social wellbeing of the Nepali people.
\end{abstract}

KEYWORDS: $\bullet$ federalism $\bullet$ monarchy $\bullet$ decentralisation $\bullet$ democracy

- transition $\bullet$ constituent assembly $\bullet$ Nepal

CorResPondence AdDRESS: Ganga Bahadur Thapa, Ph. D., Professor of Politics, Tribhuvan University, P O Box 3475, Kathmandu, Nepal, email: thapa_gb@yahoo.com. Jan Sharma, Ph. D., Tribhuvan University, Post Box 1491, Kathmandu, Nepal, email: jansharma@gmail.com. 
The 2007 Interim Constitution transformed Nepal into a Federal Democratic Republic. It basically reflects a disdain for royal or other forms of authoritarian rule, and a longing for an inclusive, representative and responsive democracy. Federalism was one of the key demands of the new leaders of the 2006 prodemocracy movement. As it is envisaged at present, there will be many governments, at least at the central, state/provincial, and local levels. How it will impact democracy depends to a large extent on how federalism is defined in terms of the levels of government, and their respective powers and responsibilities. The manner of addressing this issue will determine whether the proposed federalism is part of the solution to the democratic deficit or it becomes part of the problem.

Unfortunately, there is no constitutional theory of federalism. It exists neither in Western countries nor elsewhere. So what is federalism? According to the Stanford Encyclopedia of Philosophy, federalism is the theory or advocacy of federal political orders where final authority is divided between several units and a centre. Unlike a unitary state, sovereignty is constitutionally split between at least two territorial levels so that units at each level have final authority and can act independently of the other in some areas. Citizens thus have political obligations to two authorities (Stanford Encyclopedia, 2010). The oldest federal system is that of the United States after which Switzerland opted it in 1848, Canada in 1867, Australia in 1901, Austria in 1920, Germany in 1949, and India in 1950. More recently, Belgium adopted federalism in 1993, Spain in 1978, and Malaysia in 1963. These are successful examples of federalism. Some experiments (e.g., Czechoslovakia and Yugoslavia) have proved disastrous. While federalism is adopted by geographically large and small countries, it is also expected to address issues relating to cultural, religious, linguistic, and ethnic diversities so specific in Nepal where reluctant experience with decentralisation has not been good.

The review of the literature on decentralisation shows that federalism is concerned with the extent to which power and authority are dispersed through the geographical hierarchy of the state. It involves the concepts of politics, power and space, with a strong correlation between political freedom and development. Federalism implies that the distribution of political power and delivery of services to different groups of society play a direct role in a country's political arena, that is, regional and local issues should prevail over national ones (Blair, 1996). On the other hand, decentralisation can be defined as centrally initiated efforts to move authority and responsibility for significant governmental activities down to local government units. Although Nepal has historically experienced more centralisation than decentralisation, governance in its common usage refers to "the act, manner, function or power of government where government means an established system of political administration by which a nation is governed" (Webster, 1998). 
The debates on governance reforms in Nepal, particularly since the Constituent Assembly (CA) elections in April 2008, have been focused on an inclusive, representative, and responsive policy-making framework and process. The identification of the direction and nature of change in a political culture where small units of government are particularly suited to nourish democratic government is a difficult enterprise, yet a variety of scholars and modern studies generally agree that public attitudes favour local government because it is more understandable and capable of affecting government policies at the local level, an increasingly important source of democratic stability (Dahl \& Tufte, 1973; Markovitz, 1999). The efficacy of reforms will partly depend on what national structure of governance is expected to achieve.

Nepal's case is problematic. Its established image of democracy has declined to the level closer to the top-down, centralised and hierarchical institution of almost exclusively small groups of politicians who expect to achieve their objectives through fairly open networks of people that increasingly impinge upon government. Federalism cannot be analysed in terms of a dichotomy of decentralisation and centralisation. In order to elaborate this contention, a whole range of questions has to be confronted, questions relating to the changing character of contemporary federalism, to the complex relationship that has evolved between the state and the localities, and between the centre and the periphery (Kjeellberg, 1995). But more important, political rules are changing in Nepal, and it is essential to look more closely at the constitutional framework of the actual rules of the game by which people live and politics play even in situations with no democratic tradition.

The modern federal system of government, invented in America, has been spreading since the last two decades of the twentieth century, marked by the rise of new democracies and a new political culture (Clark \& Martinot, 1998). There are wide variations of federalism. Undoubtedly, the conventional assumption that all significant political decisions are made nationally and implemented locally builds on what is often called a centralised political system. If political parties could not tackle federalism with a new political consensus, it would lead to exacerbated social tensions in Nepal, further marginalising and impeding institutionalisation of participatory democracy, and delegitimising the state as being incapable of overcoming problems, or as being unable to withstand any threat to its stability. Authority patterns are important in affecting democratisation in a country. Nepal still maintains many traditional values that cannot be overturned in a short period of time. Democracy can be brought about through devolution of authority, and by efficiently designed institutions, which Dahl calls a pluralistic social order (Dahl, 1971). Strong and positive effects of federalism are a boon for enhancing sustainability of democratic governance because they facilitate better institutional performance (Morgan, 2007). 


\section{Contextualising and Historicising Local Government}

Over the recent past, Nepal has reluctantly experimented with decentralisation devoid of "transfer of power to people" in the political sphere as implied by political decentralisation. It also creates an environment that protects individuals against the state to enable competition and enhance efficiency, and to protect the state from being captured by narrow-interest groups, or by a dictator. While the success of the participatory programmes in attracting and sustaining citizen interest depends primarily on the design of the programme itself such as the structure of participation, the range of significant issues over which citizens' input is invited is wider, and most importantly, local government provides a much needed cushion between central politics and development activities directly affecting individuals. Since most of these changes come from political expediencies, neither significant nor sustained participation nor large advances in terms of citizen participation are possible. After Nepal had ended its self-imposed isolation in 1951, decentralisation efforts began by setting up the Royal Commission on Decentralisation in 1963. It was little more than a rhetorical exercise. Instead of starting a political process to distribute power, resources, and administrative capacities through different territorial units of a government, it turned out in hindsight to be bureaucratic deconcentration (Kafle, 1987; Agrawal).

There were no sincere efforts made until 1999 when the Local Self-Governance Act was promulgated (Dhungel, 1999). It was followed by the Local SelfGovernance Regulations in 2000. The legislation provided locally elected bodies (e.g., the District Development Committees (DDCs) at the district level and Village/Town Development Committees (VDCs/TDCs) at the village or town level) with a greater latitude and legal framework for finance and other development responsibilities such as sectoral devolution and resource mobilisation. One of the major components of the self-governance programme was the enhancement of financial, technical and managerial capacities of the DDCs. The idea was basically inspired by the success of grassroots democracy in the Nepalese Community Forest Management with user groups making major decisions. The whole idea was to transfer development initiatives to the DDCs to plan, manage and implement development activities through self-governing community organisations with the active involvement of civil society and the private sector. The hope was service delivery, e.g., health and education. They were best managed by local communities and not by central government.

In order to address institutional and policy barriers, a high-level Decentralisation Implementation Monitoring Committee was chaired by the Prime Minister. It turned out that he was too busy manipulating survival in office with little time or interest in decentralisation. Another major constraint was the limited resource base with only a portion of the land registration fee. Devolution of fiscal authority was given to the central-level Local Government Finance Commission. The VDCs were provided with the central grant of Rs 500,000, and previously, as from Rs 
25,000 . This significantly boosted distribution of resources, but there was neither appropriate monitoring mechanism nor VDC capacity for implementing development projects. In policy, it could not have been better. In practice, it could not have been worse. There was reluctance on the part of the central government to share the actual political and financial powers with the local bodies. As a result, policies and strategies were inadequate and remained on paper only. Implementation has always been promised, but never done.

For all intents and purposes, the Local Self-Government Act was meant for an elected local government with powers and resources to implant and institutionalise democratic principles at the grassroots level. It was expected to provide for structural democratic change, but in effect, it turned out to be a mere representative of the central government that had final authority to withhold, grant or withdraw powers and privileges at its free will with no questions asked (Thapa, 1998). One reason for this might lie in the fact that the powers conferred on the local bodies are often not enacted. These powers are insufficient, and it is feared that empowering local bodies will create a political opposition because of the lack of institutional capacity (NASC, 1998). If one considers enforcement aspects, it is indeed the power to delegate authority, responsibility, and resources to make local bodies capable and effective. This shows that the mere provision of authority or power in the legislation is not a sufficient condition for grassroots democracy. ${ }^{1}$

\section{Conceptual Overview: Federalism and Democracy}

Traditionally, 'dual' federalism was a system of dividing the functions between the state and national governments that gave each of them considerable autonomy within their own areas of jurisdiction (Beam, Conlan \& Walker, 1983). Federalism is a system in which political authority is divided between two or more constitutionally distinct orders or levels of government. Each one has a set of constitutional powers and an independent base of political legitimacy. The provinces can have either identical powers or 'symmetrical federalism,' or powers varied formally or informally to suit specific needs and characteristics of each province, or asymmetrical federalism. Symmetrical federalism with the right to internal self-determination would be more conducive to stable democracy in Nepal, which is what David Easton defined politics as the "authoritative allocation of values" (Easton, 1965).

In the Nepali context, several explanatory factors could be ruled out if there were a façade of a democratic regime only protecting a corrupt authoritarian oligarchy (Thapa, 2008). While no method of organising institutions is completely neutral in its impact on all those who might be affected by it "within the realm of a balanced federalism, one might prefer a somewhat greater concentration of programmes or authority at one level or another, but unless there is a clear link between citizen participation and representation in a certain function at a given level of government, democratic assertions about governmental size provide little basis for 
determining where individual programmes should be placed, or how they should be shared" (Beam et al., 1983).

This perspective does suggest that while the underlying justification for the rational choice theory of federalism derives from the distribution of public resources, and the constitutional system of division of powers (the factors influencing public policy) is the institutional context with the governmental system simple enough to facilitate citizen understanding and clear channels of accountability to safeguard individual liberty. Truly, there are a series of unresolved problems of assigning governmental functions to different levels of government in political theories of federalism in their failure to adequately address current patterns of federal politics and intergovernmental relations. In a related vein, economic theories of federalism still prohibit extensive federalism, whereas political decentralisation promotes fair, transparent, effective, and accountable institutions. However, such a tendency is probabilistic, not deterministic. The administrative perspective on federalism stresses the impossibility of effectively managing a country from a single centre. A unitary system refers to maladministration and functional autonomy-a strong executive with hierarchical organisation functional at each level, whereas political decentralisation is incompatible with such an organisation (Markovitz, 1999). This largely confirms Putman's theoretical position. He argued that even if civic associationalism makes state institutions work better, the crucial issue is the legitimisation of democracy by performance ${ }^{2}$ (Putnam, 1993).

Whereas civic organisations must be able to significantly affect the policy-making process from outside the state, then we make a strong case that the rule of law, as a key component of democratic participation, is not merely a matter of creating just institutions. While civil society cannot work by itself as a mechanism for the empowerment of marginalised groups in the context where there are vast structural impediments for the effective participation and broader influence of such groups or equalising functions that have long been associated with government in a larger social context, but certain forms of civil society may function as a multiplier of unresolved tensions and divisions in the political and social spheres, and they may help to promote mechanisms linked to democratisation $^{3}$ (Schmitz \& Gillies, 1992).

Although the concept of federalism is an outgrowth of an increasing awareness on the part of citizens, and it is a product of the community for bringing democracy to the local level, very little has been said here about the political process that undermines the actual devolvement of significant power to the local level. Arguably, representative democracy cannot be replaced. Yet, the question is how to build a new sense of community that promotes shared social networks and social capital ${ }^{4}$ (Putnam, 1993), and a governance process that facilitates the development of networking and the participation of citizens, groups and community organisations, without the local government being the centre of power 
or authority, which can overcome the shortcomings of a pluralistic democracy, i.e., democracy deficiencies (Thapa, 2007; Thapa, 2008; Sharma, 1998).

With regard to the social, economic, and political transformation, Nepal faces similar issues as other transitional countries, yet without a multilayered federal governing structure marked by consociationalism in place, which will undoubtedly produce a local democratic practice and real citizen participation in the ongoing process of building democratic practices and institutions over the population that is increasingly discontent due to increasingly unsatisfied needs, and because of being disconnected from power. It matters considerably because the Nepali political elites are responsible for negotiating the rules for drafting the constitution in the daily political game and federal structure that give a political system behavioural consolidation ${ }^{5}$ (Przeworski, 1991; Merkel, 1997) and constitutional legitimacy ${ }^{6}$, while the consolidation of civic culture and civil society completes the stabilisation of the socio-political substructure of democracy.

Power rests with the Nepali people now, and the central supremacy has been established. Nepal still has to make its way through federalism towards the creation of linear state restructuring to achieve a reasonably efficient blend of democracy, markets, and equity, which is nowadays politicised largely because it has failed to accurately describe the actual practice. Indeed, the unitary system is outmoded with its dispersion of power and control. It cannot permanently resolve the issues because every successive stage of political and economic development gives a new aspect, makes a new question, yet federalism remains the cardinal proposition of the Nepali constitutional system. Nepal faces a challenge stemming from historical and structural problems of the society, whatever the form of government. But we assume that the system of progressive or collaborative federalism with broad responsibilities in a form of accountability, and with the emergence of new identities and interests, is primarily ingrained in the character of Nepal as a political community. So, it could be more inclusive, representative and responsive.

The effectiveness of decisions can be determined, as Easton has noted, "when decision-makers are recognised by most members of the system as having responsibility for these matters, and taking actions which are accepted as binding most of the time by most members so long as they act within the limits of their roles" (Easton, 1965). In every society, we can discover its own patterns, to use Lasswell's terminology (Quoted in Cox, Ikenberry \& Inoguchi, 1999), authority "practices", yet two basic political claims have been advanced on behalf of federalism. One maintains that federalism provides the most advantageous governmental arrangements to reconcile the competing political advantages of large and small republics. The other emphasises its role in preventing concentrations of governmental power and in promoting public access to government decision-making (Beam et al., 1983). Motivationally and logistically, 
smallness is often thought to contribute to democracy by enhancing citizen participation and their control over the government.

Federalism certainly provides no clear and consistent guidance on the question concerning the proper allocation of functions and powers among governmental levels, and for managing intergovernmental programmes. A number of political scientists (Friedrich, 1968) have begun to view federalism in behavioural terms as a political process or as a bargain that has frequently been an unstable phase of political development. The decisions made at the local level is best viewed in determining the shape of the community as well as "who gets what and how." Nonetheless, federalism with its autonomous and unalterable subunits rather than with administrative or political decentralisation probably contributes to protecting individual liberty when it is part of a broader fabric of constitutional representation.

\section{$4 \quad$ Federalism: State Crafting?}

There is evidence of broad contours of post-monarchy changes in Nepal. They can be seen as peaceful transformation towards a civilian political order. Such a broader background might make one tempted to think that democratic reform is possible along with transferring power to the grassroots in support of democratically elected and controlled institutions for all intents and purposes. Yet, the continuing class and regional cleavages that dominate real politics have developed as a new pillar of conflict that hampers the constitutional reforms designed to create an institutional culture for democratic institutions. The core issue is the kind of democracy we need today and to accordingly reform the the governance structure so that it promotes good and accountable governance.

The democratic agenda has dominated Nepal since 1990. However, democratic institutions are still extremely fragile, and the search for consensual solutions through local governments remains restricted, or it is considered insignificant. The institutionalisation of the democratic order is thus fraught with risk. Nepal's transformation from a monarchy to a republic does not change the basic societal rules. Democracy and freedom require citizens to exercise independent decisionmaking and political responsibility, yet local governments are the best-endowed institutions fundamentally responsible for the transformation of the Nepali society.

The traditional local government institutions characterised by "cultures of paternalism, bureaucracy, departmentalism, hierarchy, closed local democratic deficit, and central orthodoxy are now fairly uncommon" (McGarvey, 1997). Obviously there is undoubted consensus that the distribution of power in the political and social systems within authoritarianism or the centralised system (tightly associated with communication styles where orders, control and punishment are directed from top to bottom, and where democratic culture is suppressed through the use of force rather than participation) weakens the 
democratic process (Hermochova, 1997). Nepal's political direction remains uncertain in the very near future. In such a situation, federalism allows a space for people to communicate efficiently, discuss views openly, and to negotiate solutions that are acceptable.

Decentralisation is undoubtedly part of a wider process of involving local communities in the local political process. It is often claimed that it creates an environment in which local officials have both the opportunity and the incentive to learn from policy experimentation in order to advance towards better policies and results that may transmit their wishes to the policy process Yackee and Palus, 2010). Federalism, which connects devolution, innovation and more successful policy outcome, focuses on the penetration and standardisation processes, and thereby underlining the importance of integrating peripheries, defining boundaries, and creating identities (Walle, 2010). Federalism is seen as a strategy and institutional innovation. They develop political and governing institutions that are more understanding of the needs and wishes of the ordinary people. Federalism secures institutionalisation of political and social conflicts, and it achieves the formation and adoption of political identities and roles. This helps to overcome the democratic deficit.

Even if we assume that decentralisation plays a role in organising some form of stability and social cohesion, especially by using the argument that conflict can be resolved by gradually reducing central dependence what Lijphart calls a consociational system of democracy (Lijphart, 1996; Lijphart, 1997), the democratic mandate will only be an effective tool if local politics can legitimately claim to be representative of the local communities. This approach implies that maintaining democracy or democratic stability requires that citizens agree on the limits on the state that they are to defend. Decentralisation may relieve centreperiphery tensions around long-standing grievances of the marginalised groups. The power-sharing theory holds that democracy is possible in deeply divided societies provided that consociational societies are characterised by (1) grand coalition governments that include representatives of all major linguistic and religious groups, (2) cultural autonomy for these groups, (3) proportionality of political representation and civil service appointments, and (4) a minority veto with regard to vital minority rights and autonomy in contrast to majoritarian democracy, the winner-takes-all democracy characterised by the concentration of power in the hands of a bare majority, one-party governments, centralised power, a disproportional electoral system, and an absolute majority rule, which are most probably the conditions for a stable democracy in divided democracies. Equally importantly, if decentralisation brings about a fair distribution of power and innovation, then it may also intensify inequalities among jurisdictions because some localities may be ill-equipped with weak human resources or policymaking capacities necessary to deal with the new authority (Yackee and Palus, 2010). 
In the light of deep social cleavages that characterise Nepal, it is difficult to see how the participation rights can be enough to empower them through civic engagement. Federalism reduces grievances by increasing autonomy and participation in decision-making. However, significant structural and institutional changes can result in new tensions, particularly if they are poorly planned or monitored. Gutmann and Thompson (2004) argue that variations in democratic participation can be attributed to the extent at which agents at various levels of state hierarchy encourage more direct and robust modes of popular engagement with politics. What is more important is that even if all citizens favour democracy and elections, they are likely to disagree about a range of policies, citizens' political rights, the pace of economic reform, possible further reform, and the corresponding institutions. This is the case even if the concept of elections is a heuristic device that allows establishment and stabilisation of various forms of democratic government. It cannot automatically lead to responsive or accountable participation in the democratic process. Let us take the case of India. Its ethnic and linguistic federalism has worked for sixty years, but it is 'quasi-federal or semifederal' because it has never been highly decentralised. It is even more centralised due to frequent use of the president's rule for partisan purposes, including the central government's right to dismiss state governments and to replace them with direct central rule. With its constitutionally granted autonomous state, in practice, federalism should be seen as a political arena in institutionalising efficient representation in Nepal's conflict-ridden transition.

In long-term democracies, as Lijphart (1999) summarises the evidence, federal arrangements are most common in the societies that are geographically large and/or ethnically and linguistically diverse, while the vast majority of monolingual and mono-ethnic states are unitary in form. Several scholars of comparative politics, most notably Juan Linz, have argued that presidential systems are particularly pernicious in their potential for conflict, especially when coupled with constitutional arrangements that create rival centres of power. For example, illdefined borders between presidential powers and those of the legislature can be continual irritants leading to political unrest, and it may trigger the crisis that leads to the end of democracy. Rather unsurprisingly, a federal structure with limited autonomy is indeed entirely superficial, deeply problematic, and perhaps constantly prone to not being able to give citizens the opportunity to voice their preferences, and to allow them to become politically active.

The processes of local and territorial politics are now well-grounded, and they have grown steadily, which cannot be ignored, although effects are not yet clearcut. It is difficult for Nepal to break the traditional pattern of seeking solutions. In Nepal, there is still a struggle between the forces that favour federalism and those that are in favour of a unitary state. And there are several bargaining chips and deadlocks that are becoming increasingly obvious. The main question is not whether federalism will work, but how it will work, and in particular, what representation channels, mobilisation, and socialisation will be at a time when the 
organisation and style of governance remain an open question after the overthrow of the monarchy. The state is now under the control of the parties with conflicting ideologies. It is worth noting that democracy as we understand it is not a system that bestows powers to a certain group of people. Democracy is real, provided that people are engaged in decision-making and other processes that affect their lives. In this context, federalism is certainly a good beginning.

Still more important, a modern and forward-looking nation requires a mature and reasoned political discourse, including the economic policy that deals with allocation, stabilisation, and redistribution of resources. By finding local solutions to problems, federalism gives people a real role in shaping decisions, serving the values of associational freedom such as equality of opportunity, a tension that may be particularly acute in significantly multiracial and multicultural societies, e.g., the contemporary Nepalese society. Those who wonder why every individual needs to engage in decision-making and deliberation, and to support a functioning market economy in a high-income country, it is still not clear how federalism resolves the paradox of participation that is difficult to be generalised elsewhere. It is argued that many independent, regional and ethnic movements lead to disabled and fragmented politics. But a legitimate academic question that perhaps deserves serious consideration is: what would be a feasible polity in Nepal that would help tackle different dimensions of institutionalisation, participatory democratic practices, political institutions and representation in order to enhance the quality of democracy and address extreme levels of inequality, poverty, and exclusion.

Neither a single format nor a set of institutions embodies modern democracy, even if at a given moment in time, some particular country may seem to represent "best practice" in which individuals acquire power to decide by means of a competitive struggle. Consolidation of democracy is strongly associated with five values and attitudes: rule of law, electoral accountability, participation, inter-institutional accountability, participation, and competition, which reflect democracy's capacity to give citizens an adequate answer by implementing the public policies that respond to their needs (Morlino, 2009). The extension of democracy to the state is not just a matter of elections, constitutional reform, or changes in the form of government, particularly in the countries with a long history of authoritarian rule like Nepal. Federalism should be seen as a political arena that institutionalises effective representation and political participation to enhance multiple social, economic and political transformations in the context of Nepal's long-standing problems with democracy, local interests, and sustainable socio-economic development in some cases what Dahl calls "participatory autocracy" (Dahl, 1998).

The unquestionable relevance of federalism is consistently confirmed by better results and performance when policy-making authority is within the local governments because decision-making takes place closer to the people. Federalism produces diversification and localisation of the demands to which traditional 
decentralisation is unable to respond adequately. The transfer of power under federalism provides services to its citizens in tune with local norms and values, and it creates a new and innovative programme to address community problems more effectively. It promotes better informed and responsive local governments as well as the general well-being of a community and its citizens. It helps to build strong communities and to create loyalty to the political system. It helps understand local needs and preferences by ensuring delivery of services that people actually need. The people are the ultimate judges of the performance of their local authorities in terms of both development needs and service delivery. Thus, it ensures policy effectiveness and quality of service delivery. The politically accountable local government is regarded as a decisive precondition for the functioning of the entire national and democratic character. Last but not least, it brings major improvements in terms of democratic control and political accountability (Walle, 2010; Yackee and Palus, 2010; Kuhlmann, 2010 and Thapa, 1998).

\section{$5 \quad$ Strategic Leadership}

Freedom of ordinary people, with particular emphasis on people power, tolerance for non-conforming people, and trust in people, can be observed today in many countries that seek to democratise. Yet, shamefully, Nepal has no strategic or rational $^{7}$ (Gros, 1997) political leadership committed to democracy to rally popular support against authoritarian forces whether they are Maoists or MarxistLeninists, or any others whose passions can be infectious. This does not put an end to the matter. Whereas the normative basis of democracy emphasises political completion through regular elections, the durability of democracy and the real capabilities of the state ultimately depend on the Charter of Democracy itself. Unfortunately, in Nepal, those who have acquired power and status have an interest in maintaining the status quo, institutions, and ideologies of manipulation. Therefore, we must say that such challenges can only be a bad influence that manifests itself in repressive policies and state intervention, which are less open to democratic rule. Clearly, creating a federal structure is highly complex. Yet, unless there is the will to act when the situation demands action, it is unlikely to allow people to translate democratic preferences into active support for democratic goals (Welzel, 2007). The crucial point, however, is that when leaders are both capable and willing to struggle for democratic goals, they do allow for much variation in terms of conceptualising and formulating the politics that leads to transformation. The ongoing struggle of the indigenous and regional movement for recognition of the right to self-determination raises fears of destabilisation (Kraljic \& Stolz, 2010), but it is the job of the responsive and creative leadership to mobilise and galvanise them to join the action for shared benefits.

While it is true that through various forms of autonomous arrangements, federalism allows people to develop their institutions in their own territory, and to determine their own development in accordance with their own values, it seems 
that the only way to maximize participation is to ensure the country's territorial integrity and sovereignty (Morgan, 2007). Whether the Nepalese traditional leaders, characterised by personalised leadership, will be a positive force to make the transition from a besieged to functional democracy remains to be seen. It is no less true that the poor and corrupt conduct of politicians and public institutions has consistently dampened the prospects of effective institutions of political authority requiring entirely new dimensions of social and economic arrangements that foster innovations. People are increasingly sceptical about the state's ability to deliver on its promises. In this respect, leadership is an important criterion for determining the political life in institutionalising federalism.

What one actually observes in Nepal (in the context of the history of the communist-like concentration of power, or despite the rhetoric about a pendulumlike movement between centralisation and decentralisation) are the continuous preponderance of centralism, political culture and practices, and institutions calling for reform that guarantees participation and representation contributing to strengthening democracy and the federalised institutional pattern emerging from a new form of politics that pulls together diverse people from across the political spectrum. We believe that socially peaceful transformation is an extremely complex process that needs the work of all forces. Yet, it is important to acknowledge that, firstly, Nepal needs to allow democratic self-government; secondly, the country needs to allow legitimate power to uphold autonomy so that it is no longer seen as a single body of citizens who constitute a plurality of diverse people, groups, and associations that legitimise the transformation taking place in society. All this will lead to a "democracy-accountability-state" (Bislev, 2004). Its absence diminishes the propensity of the Nepali regime to democratise. For those who advocate the centrality of participatory democracy linking citizens with the state, it may be important to know that creative leadership and an institutionalised form of governance can affect citizen expectations and reach out to higher levels of distrust in the state (Herrcros \& Criadao, 2008). Coming from the liberal perspective, the national consensus must be derived from political parties as a basis for the formulation of any reform agenda. Our assumption is that nobody can do this but the Nepalese themselves [what Shorbagy (2009) calls "only of national fabrics"] to overcome the ideological battles that have been fought in the Nepalese politics for so long. Thus, the resolved ideological conflicts are the key to any constitutional reform of shaping the Nepalese political life, and to strengthening democratic political institutions and local systems.

There are not many examples of simple and safe transition from despotism to democracy. Nepal's conflict-ridden transition dilemma under the circumstances of repressive, idiosyncratic, and ambitious leadership (which is apparently linked with traditional clientele mechanisms intended to promote themselves and their policies to the public, and in blunt terms, they raise their game "contrary to civic engagement and other forms of participation) highlights the existence of classbased inequality, and it has certainly not reached the threshold of a comprehensive 
democracy promotion with regard to being involved in those social, cultural, and associational activities in that may offer benefits at large" (Wagle, 2006). It casts a perennial shadow over the scope for greater efficiency, speed, and flexibility for the effective exercise of institutionalised forms of governance. In the present analysis, it is still difficult to ascertain whether Nepal will foster a political culture that favours participatory democracy and transforms the social structure to eventually develop a political will to reflect the shift, especially the citizens who have direct routes to influencing the policy outcomes. The problem does not end here.

While democratisation is not unlikely, most Nepalese politicians behave like Jell$\mathrm{O}$; it moves and wiggles a lot when we shake the bowl; then it returns to its original shape (Thapa, 2009b). It is not that the Nepali political leadership is unaware of the need for changes, but it is its indomitable will to hang on to power no matter what. The people are pushed to the periphery. It can be argued that while there has been some interest in conceptual change about the modernisation of the state that favours local representation, the concept is variously interpreted over its meaning that the restructuring of the political system remains open-ended, lacking an intellectual pedigree breakthrough in the process. It needs to be noted that this problem has not been unique to Nepal. So far, it has been characteristic of a generation of politicians, and those at the helm have been concerned merely with the utilitarian government. They do not really commit themselves to adopting democratic principles and values.

Differences are likely to surface between cultures, values, and aspirations as Huntington's Clash of Civilizations points out (Huntington, 1997). Through their incisive judgment and sense of responsibility, the leaders (e.g., B.P. Koirala, Ganeshman Singh, T. P. Acharya, Pushpa Lal, Manmohan Adhikari, and K.P. Bhattarai) used to guide their parties largely in the right direction. One of the most important things for a leader is that $\mathrm{s} / \mathrm{he}$ should be aware that $\mathrm{s} / \mathrm{he}$ is the pillar in unfavourable times and the motivator committed to organisational goals and aspirations. S/he should encourage people to stand up for what they believe in, and give credit when and whom it is due to, gracefully and quietly. But the exact opposite is true in Nepal. The leaders who are on the scene now not only lack these qualities, but they are also formalistic, indecisive, they favour the linear views of political development, and they are focused on material factors. The troubling paradox is that in spite of the successful struggle for a republic and numerous valid demands for systemic reforms, politicians have indulged in grabbing power and privileges rather than pursuing the national interest or public welfare what Englehart (2007) calls "self-destructive despotism." Revealingly, it could be that, to paraphrase Englehart, while functional states are all the same, weak states are weak in their own way, and most struggling democracies continue to resemble chromatically weak states only after serious miscalculations by leaders. ${ }^{8}$ Despite the mountain of problems and huge challenges that lie ahead of Nepal, there is still room for optimism. 
Ideological nuances notwithstanding, old and new democracies began to redesign their political institutions during the 1980s and 1990s. The general notion was that the government required more citizen participation and greater decentralisation to give local governments more authority and local citizens more potential instruments of participation, although in varying degrees. We may say that a balance of power between central and local government is desirable, and it is the imperative to decentralise decision-making power and to establish real local governments, as O'Donnell and Mainwaring have noted, to claim (on the basis of shared beliefs) that democracy is viable insofar as it is based on the community and society (O'Donnell, 1999; Mainwaring, 1992). If governments do nothing but umpire the group struggle, as is the case in Nepal, sheer survival or durability of democracy has to be considered as a major achievement. If not, has the political process taken place to lay down the conditions for self-sustaining democracy?

More specifically, the Nepali local government is at a turning point where it calls for a broad political and social pact for the state with a high level of organisational capacity and institutionalised rule of law. It highlights the need to complement the politics of a true democracy, involving federalism. The question is how successful the new institutions will be in actually attracting and sustaining a large number of citizen participants, or what effects of participatory mechanisms will be on local government transparency, inclusion, and wider civic engagement. Such a process, paradoxically, is too recent, and the responses to these questions are going to be varied in each case. The problems surrounding their implementation are huge, and they are going to take a long time to be resolved.

As argued elsewhere, Nepal's transition from a monarchy to a federal republic is distinct on several counts, but it encounters a number of important challenges, including constructing a culture based on sharing, reciprocity, responsibility, accountability, and mutual obligation - a primary factor that contributes to the lack of consensus regarding the concept of the state itself, and to the growth of the democratic deficit ${ }^{9}$ (Thapa \& Sharma, 2009; Thapa, 2009a; Herb, 2001). The democratic institutions created to represent the interests of people are insufficiently accountable. Transparency and effectiveness are lacking, especially the decision-making authority is centralised in the hands of the political executive. Unless the new power-sharing arrangement breaks with the centuries-old political tradition, Nepal will witness a game that is less cryptic, but far more perilous. There has been no concerted action for participatory programmes in order to sustain a large number of participants in implementing policies in various public sector activities, or in terms of local-level participatory programmes and statesociety cooperation in order to adjust to the complexities of central-local relations. This calls for a new concept of local government. While resources are critical to promote and sustain citizen participation, the Nepali political leadership lacks education, skills, and experience in managing governance. There is a poor 
understanding of the nation-building ${ }^{10}$ process and of how the fractured transition is put together. This is certainly a call neither for a return to the now discredited highly centralised regime nor for a brutal nomadic vision, but for the reconceptualisation of the Nepali state to better meet the needs of citizens, and to reflect the goals of inclusive, responsive, and accountable governance.

The Nepali politics is lurching like a drunk from crisis to crisis, and the cyclical ups and downs of political elites in response to current debate on federalism pose serious problems for rational choice. The political processes of reforming the Nepali state and building democratic institutions have been stalled for lack of consensus on this vital national agenda. The basic rules of politics are at stake, including the state's territorial integrity. Our hypothesis concerning local government is that unlike the communist system, incorporating local politics into a hierarchical political party, the emergence of the modern system with new state institutions, but without inclusive public forums and new participation programmes in the political process, participant enthusiasm is going to fade quickly. The risk is that the ruling elite, participating in the reforms, seems unwilling or unable to guarantee the continuity of the long-term policies, or to try to undo or at least thwart some modernisation reforms. Therefore, it is once again important to view the parties within a wider context: the nature of such linkages largely determines the effectiveness of local government in promoting and sustaining local participation programmes.

Federalism may not be a panacea for Nepal, but it is certainly important for the Nepali society where the organisation of the state is such that all authority and power are excessively concentrated in the central government. It is on this basis that not only politicians, but also every group have access to the state resources and patronage. The state is indeed based on personal and clientele ties with political institutions, i.e., the privatisation of the state that continues to be the driving force in the Nepali politics. Even the hybrid nature of the CA is turning to disappointment, to say the least. Democratic regimes can only survive when their societies are committed to them. There is no doubt that Nepal is in need of a substantial shift in the formal structures of local political systems, but there are certain set values (liberty or autonomy, democracy or participation) generally perceived to be essential, particularly if the government politics affects citizens' basic rights and interests. If it widens the gap between the rulers and the ruled, people may stand up against government.

From one standpoint, Nepal deserves high marks for the progress it has made towards a multi-party democracy, but the transition process is far from being complete because there needs to be certainty with regard to unshakable commitments to democratic values, to the changing character of the society. However, authoritarian elements still control the administrative bureaucracy, including the military. Federalism seems dubious on political grounds as well. It is axiomatic that democracy thrives in a competitive system, and it also fosters a 
desire for individual decision-making shaped solely by wider civic engagement, and the by the presence of national decentralisation and supportive civic culture, as illustrated in the chart below. It is no secret that without a constitutional system that combines the inclusive governance elements coupled to extensive political reforms, there will be no increase in the representation of citizens. Moreover, the state reform would allow citizen participation, and a blossoming democracy would be a far cry.

\section{Chart 1: Political System Dimensions}

\section{An ideal type of the political system}

\author{
Political System Dimensions \\ Institutional \\ (structure, powers) \\ Institutional Web \\ Procedural \\ Rules, Procedures \& Accessibility \\ Representational \\ Territorial \& Functional Structures \\ Representation
}

Policy-making mechanisms

$\begin{array}{ll}\text { Authoritarian } & \text { Democrat } \\ \begin{array}{l}\text { Fusion of powers } \\ \text { Unaccountable institutions }\end{array} & \begin{array}{l}\text { Division of } \\ \text { Accountable }\end{array} \\ \text { Hierarchical } & \text { Egalitarian } \\ \text { Unitary } & \text { Federal } \\ \text { Corporativist } & \text { Pluralistic } \\ \begin{array}{l}\text { Central planning/ } \\ \text { interventionism }\end{array} & \text { Pressure }\end{array}$

(Adapted from Ganga Thapa's forthcoming book entitled 'Nepal: The Road to Democracy')

Post-monarchy Nepal is marked by the desire for a more decentralised and market-oriented public sector, but the manner in which federalism is expressed to some extent makes it difficult to shape the content and character of contemporary local government for increased citizen participation in efforts to significantly improve governance. As the French adage says, "the more things change, the more they stay the same," the debate on the role of federalism in Nepal is more and more intertwined with the domain of the central government for the lack of a coherent perspective on contextualising the local-level participatory programmes, the absence of trust in politicians, and with the perception that democratic institutions have little legitimacy and accountability.

In a conceptual sense, if the state and local authorities are very active, the principle of local autonomy becomes part of legal rhetoric rather than part of reality. Nepal still has a long way to go from the society, based on the combination of a large and increasing number of programme participants in civic engagement, to the expansion of citizen decision-making power. As long as popular sovereignty was the standard of democracy, considerable changes occurred following the 1990 revolution, culminating in the popular uprising of April 2006. They looked like nostalgic phases in the long process of the emergence of the Nepali nation. 
There are several ways in which local government operations can be assessed. Although scholars disagree, there is no systematic relationship between the federal system and the protection of individual minorities. However, if one looks more closely at the value maintained, the multiple power centres and access points in the federal system enhance government responsiveness and improve the process of representation to protect and defend territorial minorities irrespective of legal doctrines in ethnically divided countries such as Canada, Australia, and Switzerland. The chart below illustrates the territorial structure of representation in the federal, semi-federal, semi-unitary, and unitary political systems.

\section{Chart 2: Territorial Structure of Representation of the Political System}

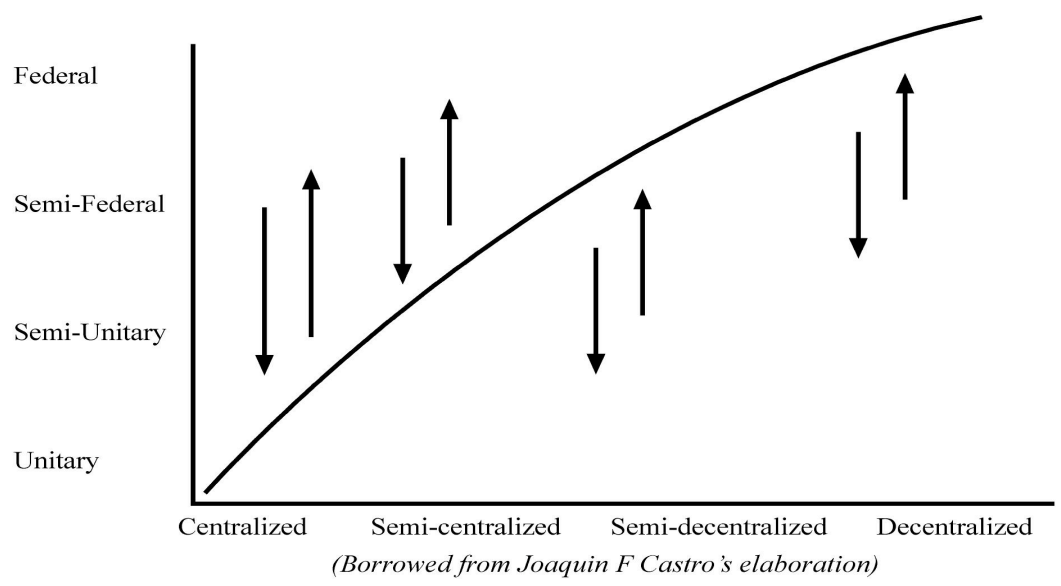

The democratic ideal in local government implies that active participation of citizens in local affairs is both a goal in itself and an instrument for strengthening democracy in society at large. Federalism may not be the final answer to the issues concerning local population. Our argument is that federalism as administrative or political decentralisation without autonomy and the right to internal selfdetermination is a futile exercise. There is no way to avoid citizen disengagement from the political system, the rules and procedures of which are illustrated below: 


\section{Chart 3: $\quad$ Rules and Procedures of the Political System}

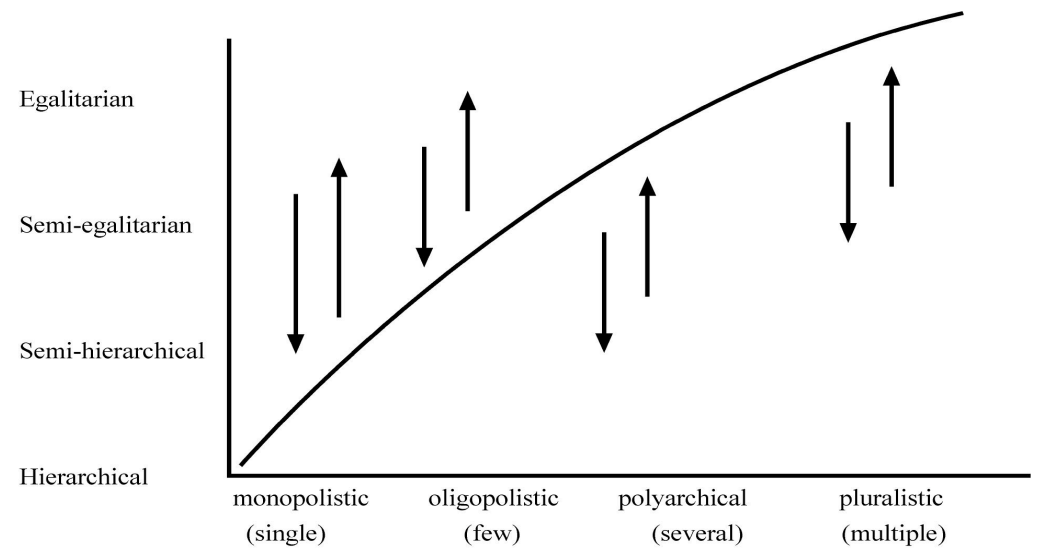

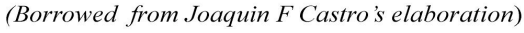

There are local government examples that choose their form of governance, and there are communities where local powers are defined by the centre, but most countries do not allow local autonomy to decide on its form of governance. Even at the theoretical level, the contentions are about what kind of political-structural specificities and variations can be maintained for different countries. Federalism is strong in some countries, but it is hardly visible in others. By itself, this is not particularly remarkable. The sharply conflicting assessments of the current theories of federalism reveal that the discourse is increasingly focused both on what institutional options are suitable for a particular country and on their desirability. Nepal represents a picture of one of the most complex multiethnic societies. It is still organised in terms of the hierarchy of race, gender, class, etc. New institutional mechanisms are best achieved if economic and political priorities are accompanied by a transformation of both the short-term empowerment of the poor and the long-term consolidation of democratic institutions.

\section{Building a Democratic Community}

The most appropriate type of government remains debatable, but the constitutional structure is without doubt the foundation of democracy. Elites are responsible for negotiating the rules for drafting the constitution, and for upholding the constitutional procedures in the daily political game. Moreover, democratic governance can work only when citizens are responsible to themselves, and thereby also demonstrating a reasonable commitment to their community. To build a democratic community, the social reality of a community, which shapes social relations, must be understood. The leading authorities agree on the theory of 
the modern democratic state where democratic institutions must have a local foundation. Yet, some common ground needs to be articulated to genuinely push local democracy so that it is composed of self-governing institutions to build a strong democratic community in which individuals, groups, and collectivities of all kinds treat themselves as parts of a creative society seeking liberation from all forms of domination (Mohanty, 1998).

There is virtually no intensive debate on the models of democracy to be preferred (Held, 1996). Local governance is an important democratic alternative for sustaining public solidarity and community participation. In local governance, participatory politics can bring people out of isolation into a community to create a context of enhancing individual autonomy and citizenship. In fact, the spread of democratic ideas and the emergence of a global system have contributed to a resurgence of local initiatives. The pressures for democratisation have led to a new emphasis on local governance as illustrated below.

\section{Chart 4: $\quad$ Society and State}

$\begin{array}{ll}\text { Category } & \text { Power } \\ \text { Elites } & \text { Political issues, access to power } \\ \text { Spoilers } & \text { Personal wealth and power } \\ \text { Citizens } & \text { Economic concerns, basic life necessities } \\ \text { Victims } & \text { Justice, revenge } \\ \text { Social groups } & \text { Security in society }\end{array}$

It is most likely that the CA will provide for a three-tier federal government structure consisting of the central government, state/provincial governments, and local governments. Ten thematic committees and a Constitutional Committee are working on building the Nepali state and the federal structure. The CA Committee on State Restructuring and Distribution of State Powers considered its subcommittee report that had proposed two alternative models for the federal system: the first model with 14 provinces and the second model with six provinces. On 20 January 2010 , the main committee, by a majority vote, decided on 14 provinces based mainly on ethnic identities with some changes in the names and alignments of ethnic settlements. Most significantly, the main committee also recommended prior political rights of ethnic community leadership in the special structures to be established in provinces for at least two consecutive elections. The state is divided into the following provinces (from west to east): Khaptad, Jadan, Karnali, Tharuhat-Awadh-Lumbini, Magarat, Tamuwan, Narayani, Tamsaling, Newa, Mithila-Bhojpura-Madhesh, Sunkoshi, Sherpa, Kirat and Limbuan, as shown in the map below: 


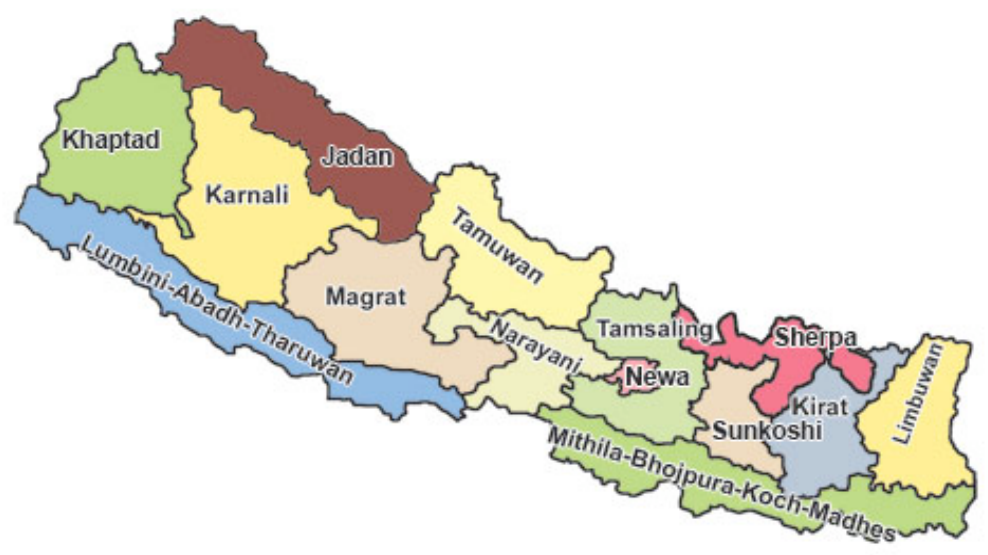

(Source: myrepublica.com)

The stage is thus set for the CA to finalise the recommendation, and to take a decision on whether the provinces will remain as provinces or as states / republics. The precise number of provinces and their geographical alignments need to be determined if they are to be changed. There is also an option to come up with a new or better alternative, if any. It may be noted that among the three key players, the Unified Communist Party of Nepal (Maoist) (UCPN-M) has proposed 14 "autonomous republics," the Communist Party of Nepal (Unified MarxistLeninist) (CPN-UML) has proposed 15 provinces, whereas the Nepali Congress (NC) has remained confused and undecided. The Communist Party of Nepal (Marxist-Leninist) (CPN-ML) and the Communist Party of Nepal (United) (CPN$\mathrm{U})$ have proposed six and eight provinces respectively.

Given this wide divergence in the nature and pattern of the federalism proposed by major political parties, the CA endorsement is unlikely to win universal support. It would be least surprising if the main opposition to the proposed provinces came from the Tarai-based political parties and groups because the main committee is in favour of the creation of two provinces in the Tarai bordering India where groups ask for "one Madhesh, one province" with the right to self-determination. This is a potential recipe for the new series of conflicts, even intense ones, if such regional movements obtain extraneous support. Apart from this, the division of powers and responsibilities is already being worked out to meet the tight deadline of promulgating the new constitution (the country's seventh constitution in six decades) by 28 May 2010 .

Federalism must serve the interests of popular sovereignty by placing government closer to the people, allowing citizens to pursue their interests through several governments rather than through the traditional perception of separation of powers 
in the name of democracy by believing that a true democracy arises ultimately from a direct democracy in a small community in which citizens are thought to be more familiar with issues and leaders. Besides, the consolidation of civic political culture and civil society completes the stabilisation of the social and political structure of democracy. It is not a problem, however, if some of the characteristics tend to favour democracy, while the others tend to work against it.

In recent years there has been a flowering of federalism or self-government initiatives among developing countries. The range and diversity of these initiatives are quite impressive, reflecting the different historical, cultural, and political conditions of various countries. One theory of the modern democratic state is that liberalism aims at creating a society where the obtained conditions enable the individual to exercise her or his capacity of self-rule. The democratic idea centres upon the assumption of the capacity of individuals as citizens to govern themselves. It is assumed, first, that every adult can be rightly considered to be, in principle, sufficiently well qualified to participate in the democratic process of governing the state to whose laws they are subjected. It is further assumed that among adults, no persons are so definitely better qualified than others to govern the state, and that they should be entrusted with complete and final authority over the government of the state.

It is crucial to understand that modern political liberalism aims at ensuring that the democratic process is politically organised. Individuals must be members of the state, and they must be its "nationals" in order to have citizenship rights. Popular sovereignty is thus understood as the self-rule by nationals in their capacity as citizens. This liberal conceptualisation of popular sovereignty is premised upon the acceptance of this dual notion of self-determination: the capacity of individuals to govern themselves, and the capacity of individuals as citizens to govern a political community (Teune, 1996).

Again, a number of pluralist writers have maintained that power is fairly evenly dispersed in society with no single group having ultimate control over all issues. As Arbalester reminds us, the core meaning of democracy "may be vague, but at its root lies the idea of popular power, of the situation in which power, and perhaps authority too, rests with people" (Arbalester, 1997). As democratisation has been a favourite object of study since the collapse of state communism, an essential element in the political theory of federalism stems from the view that a genuinely democratic government can flourish only in a small political entity, and that it can serve as a very good and easy-to-measure dimension of consensus democracy (Lijphart, 2008). For this reason, as Dahl puts it, "it is nearly selfevident as to require no discussion" that "the greater the belief in the legitimacy of the institutions of polyarchy within a country, the greater the chance for a consolidated democracy" (Dahl, 1971). 
In this brief paper, we attempt to argue that federalism is not an end in itself, but devolution of power. It is rather a central mechanism for understanding democracy to guide the institutionalisation of the federal democratic republic. The debate on whether Nepal needs federalism came to an end on the very day when the Interim Constitution transformed Nepal into a Federal Democratic Republic. Nepal, of course, is not yet a democracy because the centre has power monopoly. Our discussions on federalism are obviously impressive, but concerns still remain rather strong regarding the political communities' professed commitment to enacting meaningful reform of local governance in the interest of democratic governability.

One cannot fail to note that state institution building is a complex process that requires agreement on multiple issues, including centralisation of coercive powers, the division of power between the centre and periphery. However, the new state institutions, imposed by external actors, are likely to be fragile and unable to generate authority within society. Of course, when rulers benefit from state weaknesses, they will have no interest in measures that strengthen the state to their misfortune. It would not be inaccurate to say that Nepal is in the middle of a range of debates that may decide the future shape of federalism and democracy. Anyway, we cannot import it as if it were KFC or Pizza Hut, or Coca Cola. Federalism cannot be imported like refrigerators or computers, it can only be shared. The best option would be federalism which would provide for autonomy and cultural pluralism, where local and central sovereignty are cooperative and coequal. We can, however, deal with enlightened, effective, and realistic themes. Yet, principled policies need to transform society where government is run by commonly accepted and binding rules. Democracy can best provide prosperity, independence, and liberty for which the Nepali people have struggled and suffered for so many years.

There are some practical obstacles to participation and fairness. We need to resolve some issues, for instance, how to decide which groups are entitled to greater representation, and how to ensure that their representatives are in fact accountable. Federalism is first and foremost a federation of peoples. The decisions regarding the powers of the federal subunits should recognise and affirm the equal status of the disadvantaged and marginalised groups or regions that need special representation. Nepal is a country of great diversity: there are varied ethnic groups, varied resource bases, and varied climate patterns. Therefore, a strategic response is needed in order to make the right choices that can become a model without threatening the stability and integrity of the Nepali state.

Since 1990, the main tendency of the democratic process has been to produce several parties that have a potential plurality status, but no single party can realistically strive for setting up a federal structure. The Nepali case study does not 
analyse a single event, but a series of events that have occurred over 60 years since Nepal's first democratic opening in 1951 when democracy and popular sovereignty tended to degenerate into the tyranny of the majority (or to worse than that). The problem of Nepal's democratic deficit is the centralised authority of political leaders who want a total and unchallenged grip on the political process. Another problem is the politics that is less based on ideas and ethical concerns, but more on material advantages and state resources rather than public goods. Nepal's political future seems largely to depend on an emerging class structure and class relations. However, if substantive democratic reforms are combined with faster economic development, they will enhance the prospects of democratic transformation and good governance based on the political system that is inclusive, accountable, and responsive. If this is not the case, the prospects are rather bleak.

\section{Aknowledgements}

An earlier version of this paper titled 'Debating Federalism and Democracy in Nepal' was presented at the International Seminar on Federalism in Nepal: Challenges and Opportunities organized by the Centre for the Study of Nepal, Faculty of Social Sciences, Banaras Hindu University (BHU), India, and Centre for International Relations, Tribhuvan University (TU), 29-30 January 2010, Kathmandu. The authors are grateful to the seminar organisers and participants for their thought provoking comments on the previous version of the article. However, we would especially like to express our sincere gratitude to Professor Anjoo Sharan Upadhyay, Coordinator, Centre for the Study of Nepal, BHU for her encouragement and crystallizing thoughts she accorded to us during the entire period of the seminar. The authors, however, jealously claim full blame for any errors, foibles, and follies as revealed in this essay.

\section{Notes}

${ }^{1}$ The promulgation of the 1999 Local Self-Government Act (although it theoretically envisages that local government should be elected and should have the power and resources to exercise effective political authority) was an effort to institutionalise democracy on the basis of political pluralism. It can be seen as an indication of the desire to implant democratic principles into the grassroots. However, their functioning can be merely seen in the central government that may withhold, grant or withdraw power and privileges as it deems fit. One reason for this is that the powers conferred on the local bodies are often not enacted, or for fear of creating political opposition because of the lack of institutional capacity, or enforcement is poor.

2 Sidney Tarrow Putnam's Making Democracy Work: Civic Traditions in Modern Italy tackles two problems in social science: how to marry directly collected quantitative data to the historical information from external sources, and how to connect political culture to democracy. Still more impressive is how traditions of association and civic engagement affect political behaviour.

${ }^{3}$ In this context, developing democracy is fundamentally about developed citizenship, and about building a strong civil society, which gives people an effective voice in the governing institutions and development plans that affect their lives. Civil society is distinguished from the formal structures of the state, yet pluralist democracy encourages a strong associational 
life uncontrolled by the sate, which helps to mediate between the state bodies and the multiplicity of private interests and diverse expressions of public opinion.

${ }^{4}$ Social capital is a concept often stressed by economists in order to explain and understand various human relationships as well as people's connections to associations and community affairs; it is used as a framework for bridging theory and practice as local citizens develop a vision for collective action through mutual trust and cooperation in society and community.

${ }^{5}$ We use here a narrow definition of behavioral consolidation as formulated by Adam Przeworski (1991) and Wolfgang Merkel (1997). It refers to reducing the attractiveness for powerful actors such as military, large landowners, businessmen, radical movements, clandestine groups, or populist, charismatic leaders who pursue interests outside the democratic institutions and against the democratically legitimated representatives.

${ }^{6}$ The legitimacy of a democratic system is not static. While it is not solely generated by the legality and democratic quality of constitution-making, Lipset and others argue, no matter what kind of defects the political system might have, it is legitimate so long as it is perceived by the governed to be the best realistic alternative imaginable. Moreover, in constitutional law, the legitimacy of democratic constitution is derived primarily from its own enactment, which can be differentiated into three levels: legitimacy from above, internal procedure legitimacy, and legitimacy from below.

${ }^{7}$ Strategic leadership is political leadership involving the setting of clear priorities and making difficult choices, resolving conflict and balancing different demands and views, and as such, it entails arbitration and persuasion. By rational leaders we mean that leaders act to maximize the net gains resulting from a deliberate process of decision-making. The success of democratic government (in the countries that are newly endowed with it) depends on rational leaders committed to democratic ideals. Leadership is crucial because emerging democracies often have important groups that are loath to accept the rules of the democratic game. The elites that have held onto power by hook or by crook for a long time may be ready to finance a coup d'etat before the ink is dry on the new ballots.

${ }^{8}$ The distinction between weak, failing and collapsed states, according to Robert Roteberg, is that weak states have a low capacity to make and carry out policy, but the state apparatus is not significantly challenged by other actors. Failing states are challenged by others - local elites who usurp much of their power, criminal gangs that operate in defiance of the state, or active insurgencies. Collapsed states are those where government has failed entirely, either there may no longer be any central government or the central government may be entirely powerless, see Ibid. The debate over this prediction is vigorous and voluminous.

${ }^{9}$ In the mainstream political science, the prominent explanation of the democratic deficit is not given by culturists, but instead there is a focus on the social structure. Even then, we do not speak of the preservation of the liberal polity here, but instead, we speak of the power of the political elite. Especially there where powerful antidemocratic parties, ideologies, and forces are alike, liberal democracy is less likely to emerge, and if it does emerge, it is less likely to endure.

${ }^{10}$ Nation building is generally a pejorative term used to describe effects on reviving and rebuilding governance, peace, stability, and rule of law. 


\section{References}

Agrawal, A., Britt, C. \& Kanel, K. (1998) Decentralization in Nepal: A Comparative Analysis (Oakland, California: Institute for Contemporary Studies).

Arblaster, A. (1997) Democracy, 2nd Edition (Delhi: Bookland Publishing Co.).

Beam, D. R., Conlan, T. J. \& Walker, D. B. (1983) Federalism: The Challenge of Conflicting Theories and Contemporary Practice, In: Finifter A. W. (ed.) Political Science: The State of the Discipline, pp. 247-279 (Washington DC: American Political Science Association).

Bislev, S. (2004) Globalization, State Transformation, and Public Security, International Political Science Review, 25(3), pp. 281-296, doi: 10.1177/0192512104043017.

Blair, H. W. (1996) Democracy, Equity and Common Property Resource Management in the Indian Subcontinent, Development and Change, 27(3), pp. 475-500, doi: 10.1111/j.1467-7660.1996.tb00600.x.

Clark, T. N. \& Hoffmann-Martinot, V. (ed.) (1998) The New Political Culture (Boulder: Westview Press).

Cox, M., Ikenberry, G. J. \& Inoguchi, T. (eds) (1999) American Democracy Promotion: Impulses, Strategies and Impacts (London: Oxford University Press).

Dahl, R. A. (1998) On Democracy (New Haven: Yale University Press).

Dahl, R. A. (1971) Polyarchy: Participation and Opposition (New Haven: Yale University Press).

Dahl, R. A. \& Tufte, E. (1973) Size and Democracy (Stanford CA: Stanford University Press).

Englehart, N. A. (2007) Governments Against States: The Logic of Self-Destructive Despotism, International Political Science Review, 28(2), pp. 133-153, doi: 10.1177/0192512107075403.

Easton, D. (1965) A System Analysis of Political Life (New York: John Wiley).

Friedrich, C. J. (1968) Trends of Federalism in Theory and Practice (New York: Praeger).

Government of Nepal (GoN) (1998) Local Self-Governance Bill 2055 (1998) (Kathmandu: Government of Nepal) (English translation of act by Danish International Development Agency-DANIDA), Kathmandu. n.d .

Gros, J. G. (1997) Haiti's Flagging Transition, Journal of Democracy, 8(4), pp. 94-109, doi:10.1353/jod.1997.0058.

Gutmann, A. \& Thompson, D. (2004) Why Deliberative Democracy? (Princeton NJ.: Princeton University Press).

Held, D. (1996) Models of Democracy (Stanford California: Stanford University Press).

Herb, M. (2001) Ideas and Democratic Deficit (seminar paper delivered at Annual Meeting of American Political Science Association, San Francisco, August 30 to September 2).

Herreros, F. \& Criado, H. (2008) The State and the Development of Social Trust, International Political Science Review, 29(1), pp. 53-71, doi: $10.1177 / 0192512107083447$.

Hermochova, S. (1997) Reflections of Living Through the Changes in Eastern Europe, The ANNALS of the American Academy of Political and Social Science, 552(1), pp. 107113, doi: 10.1177/0002716297552001010.

Huntington, S. P. (1997) The Clash of Civilizations: Remaking of World Order (New York: Touchstone Rockefeller Center).

Kafle, M. P. (1987) Decentralization Scheme in Nepal, In: Gurung, S. B. \& Roy, P. (eds) Planning With People: Decentralization in Nepal, pp. 11-28 (Delhi: Orient Longman). 
Kjellberg, F. (1995) The Changing Values of Local Government, The Annals of the American Academy of Political and Social Science, 540(1), pp. 40-50, doi: $10.1177 / 0002716295540000004$.

Kuhlmann, S. (2010) Between the State and the Market: Assessing Impacts of Local Government Reforms in Western Europe, Lex Localis - Journal of Local SelfGovernment, 8(1), pp. 1-21, doi:10.4335/8.1.1-21(2010).

Kraljic, S. \& Stolz, A-B. (2010) Indigenous Peoples: From Unrighteousness to the Right to Self-Government, Lex Localis- Journal of Local Self-Government, 8(1), pp. 35-63, doi:10.4335/8.1.35-63(2010).

Lijphart, A. (1996) The Puzzle of Indian Democracy: A Consociational Interpretation, American Political Science Review, 90(2), pp. 258-268.

Lijphart, A. (1997) Unequal Participation; Democracy's Unresolved Dilemma, American Political Science Review, 91(1), pp. 1-14.

Lijphart, A. (1999) Patterns of Democracy: Government Forms and Performance in ThirtySix Countries (New Haven: Yale University Press).

Lijphart, A. (2008) Thinking About Democracy: Power sharing and majority rule in theory and practice (Rutledge: New York).

Mainwaring, S. (1992) Transitions to Democracy and Democratic Consolidation, In: Mainwaring, S., O'Donnell, G. \& Valenzuela, J.S. (eds) Issues on Democratic Consolidation: The New South American Democracies in Comparative Perspective, pp. 294-341 (Helen Kellogg Institute for International Studies: University of Notre Dame).

Markovitz, I. L. (1999) Constitutions, The Federalist Papers, and the Transition to Democracy, In: Anderson, L. (ed.), Transitions to Democracy, pp. $42-71$ (New York: Columbia University Press).

McGarvey, N. (1997) Creating a New Democracy? Current Issues in Local Democracy, Contemporary Political Studies, 2, pp. 624-635 (Nottingham UK: The Political Studies Association of the United Kingdom).

Merkel, W. (1997) The Consolidation of Post-Autocratic Regimes: A Multilevel Model, (paper delivered to International Political Science Congress, Seoul August 17-21).

Morgan, R. (2007) On Political Institutions and Social Movement Dynamics: The Case of the United Nations and the Global Indigenous Movement, International Political Science Review, 28(3), pp. 273-292, doi: 10.1177/0192512107077099.

Mohanty, M. (1998) Social Movements in Creative Society: Of Autonomy and Interconnection, In: Mohanty, M., Mukerji, P. N. \& Tornquist, O. (eds) People's Rights Social Movements and the state in the Third World, pp. 63-81 (Delhi: Sage Publications).

Morlino, L. (2009) The Quality of Democracy: An Agenda for Future Research?, Participation, 33(2), pp. 3-4.

Nepal Administrative Staff College (NASC) (1998) Government Assessment in Nepal (Kathmandu: NASC).

O'Donnell, G. (1999) Counterpoints: Selected Essays on Authoritarianism and Democratization (Notre Dame: University of Notre Dame Press).

Przeworski, A. (1991) Democracy and the Market: Political and Economic Reforms in Eastern Europe and Latin America (Cambridge: Cambridge University Press).

Putnam, R. D., Leonardi, R. \& Nanetti, R. Y. (1993) Making Democracy Work: Civic Traditions in Modern Italy (Princeton NJ: Princeton University Press).

Roteberg, R. (ed.) (2003) State Failure and State Weakness in a Time of Terror (Washington DC: Brooking Institution Press).

Schmitz, G. J. \& Gillies, D. (1992) The Challenge of Democratic Development: Sustaining Democratization in Developing Societies (Ottawa: The North-South Institute). 
Sharma, J. (1998) Democracy without Roots (Delhi: Book Faith India).

Shorbagy, M. (2009) Egyptian Views on the Politics of Egypt Today, International Political Science Review, 30(5), pp. 519-534, doi: 10.1177/0192512109352458.

Stanford Encyclopedia of philosophy, Avaliable at http://plato.stanford.edu, January 15, 2010.

Roteberg, R. (ed.) (2003) State Failure and State Weakness in a Time of Terror (Washington DC: Brooking Institution Press).

Schmitz, G. J. \& Gillies, D. (1992) The Challenge of Democratic Development: Sustaining Democratization in Developing Societies (Ottawa: The North-South Institute).

Tarrow, S. (1996) Making Social Science Work across Space and Time: A Critical Reflection, American Political Science Review, 90(2), pp. 389-397.

Teune, H. (1995) Local Government and Democratic Political Development, The Annals of the American Academy of Political and Social Science, 540(1), pp. 11-23, doi: 10.1177/0002716295540000002.

Thapa, G. B. (1998) Promoting Participatory Democracy in Nepal, In: Thapa, G. B. (ed.) Promoting Participatory Democracy in Nepal: An Assessment of Local SelfGovernment, pp. 1-17 (Kathmandu: Political Science Association of Nepal).

Thapa, G. B. (2008) Nepal: From Authoritarianism to Democracy, In: Behera, N. (ed.) International Relations in South Asia: Search for an Alternative Paradigm, pp. 152-176 (Delhi: Sage Publications).

Thapa, G. B. (2009a) Is there a democratic deficit in Nepal? The political paradox, The Himalayan Times, 27 December.

Thapa, G. B. (2007) Nepal; Deficiencies in Democracy and Legitimacy of Conflict, The ICFAI Journal of International Relations, 1(2), pp. 7-30.

Thapa, G. B. (2009b) Nepali dilemma: A vibrant democracy or destructive politics?, The Himalayan Times, 21 August.

Thapa, G. B. \& Sharma, J. (2009) From Insurgency to Democracy: The Challenges of Peace and Democracy Building in Nepal, International Political Science Review, 30(2), pp. 205-219, doi: 10.1177/0192512109102437.

Van De Walle, S. (2010) Building Local Communities: Place-Shaping as Nation-Building, Lex Localis - Journal of Local Self-Government, 8(1), pp. 23-33, doi:10.4335/8.1.2333(2010).

Wagle, U. R. (2006) Political Participation and Civic Engagement in Kathmandu: An Empirical Analysis with Structural Equations, International Political Science Review, 27(3), pp. 301-322 (California: Sage Publications), doi: 10.1177/0192512106064464.

Webster's New World Dictionary (1998) Third College Edition (New York: Simon and Fraser).

Welzel, C. (2007) Are Levels of Democracy Affected by Mass Attitudes? Testing Attainment and Sustainment Effects on Democracy, International Political Science Review, 28(4), pp. 397-424, doi: 10.1177/0192512107079640.

Yackee, S. W. \& Palus, C. K. (2010) Learning from Experience? Second-Order Policy Devolution and Government Responsiveness, Lex Localis - Journal of Local SelfGovernment, 8(1), pp. 65-92, doi: 10.4335/8.1.65-92(2010). 